\title{
Deconstructing the Neoliberal Character of the European Union: A Major Source of Leftist Dissent Over the EU in Turkish Civil Society
}

\section{Can Büyükbay*}

\begin{abstract}
This article aims to contribute to the discourse of Euroscepticism in Turkish civil society by examining the underlying dynamics of the phenomenon among leftist groups. Methodologically, semi-structured qualitative interviews with and surveys of Civil Society Organisation (CSO) leaders and Critical Discourse Analysis (CDA) are applied. Compared to business organisations, a large part of the trades unions have a cautious approach towards European integration. Generally, the leftist leaders do not perceive the EU process strategically or as a political opportunity structure to gain influence, but predominately more ideologically, as the spread of neoliberal free market policies that create an anti-labour environment.
\end{abstract}

Keywords: Neoliberalism, Euroscepticism, Civil Society, European Integration, Critical Discourse Analysis

\footnotetext{
*Assistant Professor, Turkish-German University, buyukbay@tau.edu.tr
} 


\section{Introduction}

This study examines the construction of European discourse within the left-wing Turkish civil society and investigates which argumentation strategies contribute to the construction of Euroscepticism within the context of Turkey`s European Integration process. The focus on civil society is necessary as civil society actors gained more influence in this process and "the state has a legitimacy problem in maintaining its position as the primary context for politics, as a result of the shift towards civil society and culture as new reference points in the language and terms of politics," . However, not all civil society actors have been supportive of the European Integration Process. For example, in contrast to business associations that triggered the accession process, most labour unions have been critical of European Integration.

Furthermore, developments in Euroscepticism research makes such an investigation necessary. The Collaborative Research Network on Euroscepticism (Euroscepticism CRN) organised a conference entitled "Euroscepticism beyond the party system and into civil society" at Loughborough University on 5 November 2011. This event was convened on the basis of the observation that the EU integration process is no longer one driven by political parties, but the EU is engaged in an increasing dialogue with civil society. The presentations at the event examined how Euroscepticism is framed in civil society and the workshop aimed to refine and challenge the concept of Euroscepticism in considering multiple contestations of European integration and in so doing expand the research on Euroscepticism. With existing scholarly attention predominantly focused on party politics and public opinion, the question of how Euroscepticism is advanced in civil society discourse appears relatively untouched. Noting that all social actors can help to define the European question ${ }^{2}$, this study focuses on an analysis of leftist civil society leaders that have so far been ignored.

The decision to investigate civil society discourse through the argumentation strategy of the CSO leadership is based on the rationale that a strong leadership is present in contemporary Turkey: Kabasakal and Bodur ${ }^{3}$ maintain that leaders have historically had huge power in Turkish society and are expected to guarantee strong leadership. Since civil society leaders ${ }^{4}$ play an extremely important role in the national debates on European integration ${ }^{5}$ and a strong leadership culture is present in Turkey, I will concentrate on their arguments in this thesis. I will assert, as did Diez ${ }^{6}$, that discourses determine action more than preconceived interests. Moreover, the perception of the EU is prone to more rapid change in developing European state, because of the rapidly changing nature of the social and economic transition. ${ }^{7}$ To provide ample textual material to analyse the social construction of Euroscepticism, I conducted 18 semistructured interviews with CSO leaders. I then checked my results with 12 surveys to increase the internal validity of the research.

The structure of this dissertation is as follows: The literature review and theoretical approach are presented in the second part. After summing up the state of the research on Euroscepticism in theoretical and case-specific terms, the methodology will be laid out in the third part, where the research design is presented, the case selection will be justified. The empirical part sets out the ways in which Europe and the EU are systematically constructed through the interviews. The conclusion brings together the arguments from the preceding chapters, signifies new arguments and places the empirical findings in relation to the broader conceptual debates of Euroscepticism.

\section{Definition of the Euroscepticism and Literature Review}

Marks and Steenbergen's book ${ }^{8}$ and research done by Della Porta ${ }^{9}$ focus on social movements and fill a gap in the literature regarding perceptions of the EU within civil society. Chamore ${ }^{10}$ provides an important contribution to the debate by distinguishing between Euroscepticism and anti-Europeanism by undertaking a case study in the United States. Hainsworth et al. ${ }^{11}$ analysed the Euroscepticism of the right of French politics as exemplified by elements of the extreme right, Front National, the Eurosceptic, Mouvement pour La France (founded in 1994 by its leader, 
Philippe de Villiers) and the broader Gaullist movement. This focused on the issues of extreme nationalism, the long history of nation-state building and imperialism. They conclude that for these right-wing groups, historical positions on the primacy of national unity, national sovereignty and the nation-state may lead to a deep distrust of supranational structures and institutions, and consequently opposition to the EU. ${ }^{12}$ Milner ${ }^{13}$ focusses on the attitudes of the main left-wing French groups to European Integration since the early 1990s. She founds that Euroscepticism is

I 56 rooted in a lack of confidence in political elites, lack of democratic participation among citizens in decision-making at the EU-level and the spread of neoliberal policies and thus concludes that leftwing Euroscepticism in France can be labelled as soft rather than hard Euroscepticism according to the Taggart and Szczerbiak's ${ }^{14}$ definition, meaning scepticism towards specific policy areas rather than principled opposition to European integration.

As for the Turkish case, analyses regarding the attitudes of domestic actors on Turkey's relations with the EU includes the roles of members of the Turkish Parliament, ${ }^{15}$ military ${ }^{16}$, political parties ${ }^{17}$, public opinion ${ }^{18}$, business associations ${ }^{19}$ and the trade unions ${ }^{20}$. The literature on Euroscepicism includes very few approaches that seek to understand actors beyond public opinion and political parties, with a few notable exceptions ${ }^{21}$. In a recent article, Fitzgibbon seeks to enlarge the study of Euroscepticism to embrace civil society and tries to develop a framework of analysis in taking social movement literature into account.

\section{Civil Society and Case Selection}

The European Union has a set of definitions of civil society. The White Paper on European Governance $^{22}$ defines civil society in reference to a broad range of CSOs, including NGOs (nongovernmental organisations) such as environmental organisations, human rights organisations, and labour-market players such as trade unions, employer associations and professional organizations. ${ }^{23}$ Moreover, according to the EU's definitions, business associations, religious communities and the media also represent civil society. The CONECCS-EU Civil Society Database $^{24}$ considers organisations such as commercial unions, syndicates, political interest groups, local administration unions, service and production unions and religious interest groups as organisations of civil society. Apparently, the strength of a CSO is based on many variables such as the financial resources, membership profile, networking capabilities, appearance in the media etc. Therefore, I have taken such variables into consideration in selecting the cases. In selecting the cases, I examined more than twenty articles that have selected the most important CSOs for their own research in the Turkish context. After analysing various documents and articles about Turkish civil society, CSOs were selected on the basis of a combination of three qualitative criteria:

1. Consultations with academics and experts doing research on civil society in Turkey

2. An analysis of their presence in the scientific articles that indicates influence of the CSOs on political debates

3. Involvement of the CSOs with the European issues and their ethnic and ideological orientation.

Moreover, the case selection was checked with the largest CSO databases: STGM (Civil Society Development Center) and CSO Information Center at the History Foundation of Turkey. In general, I conducted interviews with one executive with either the leader or one of the three highest-ranking individuals in the organisations listed. Influential social scientists claim that not all civil society actors have been supportive of the European Integration Process. To illustrate, in comparison to business associations that have triggered the accession process, most of the labour unions have been critical towards the European Integration. ${ }^{25}$ Therefore, I concentrated mainly on 
trade unions rather than business associations. The key aim of the fieldwork, which took place in Istanbul and Ankara between January 2012 and July 2012, was to unpack the contents and learn more about Turkish civil society leaders' discourses about Europe and the European Union.The interviews were conducted in Turkish and are semi-structured - neither a closed questionnaire nor an open, everyday conservation. ${ }^{26}$ Qualitative, semi-structured interviews seem well placed to enable access to the type of information required for solving the research challenge presented here. In addition to factual information, semi-structured interviews can provide insights into the context within which the interaction and decision-making among the different actors takes place. By interviewing members of the elites, I had privileged access to the basic experience of the elites in the current political situation in Turkey and their perceptions of Europe. ${ }^{27}$

\section{Critical Discourse Analysis}

The notion of discourse in this dissertation is tied to a specific understanding of language, which is both an influencer on and influenced by social reality. It has a constitutive role in social structures and relations. These discourses consist of argumentation, metaphors and various linguistic tools. Similar discursive practices can be reformulated in different contexts, which can be described as intertextuality. ${ }^{28}$ Discourses do not cause, but enable certain actions by "setting limites to what is possible to be articulated," accordingly, they lead to "political struggles" between different versions of social reality. ${ }^{29}$ Discourse analysis is valuable in demonstrating the discursive strategies utilised by internal actors in dealing with the different visions of Europe in which these discourses play a constitutive role. This study examines an aspect that has remained largely neglected in the literature on European integration, namely civil-society based Euroscepticism via a critical perspective. More specifically, the data analysis methodology of this study is based on the multidisciplinary theoretical framework of CDA. CDA is a method of discourse analysis that deals with the relationship of language to socio-political processes and the power relations associated with them. ${ }^{30}$ It is based on earlier studies by Foucault, Bakhtin and Gramsci, and seeks to combine linguistics and sociological approaches within the analysis of the discourse in order to examine the complex interactions between discourse and society. ${ }^{31}$

CDA has both an ideological and epistemological content and an empirical technique. It analyses discourse as a text in context with two basic concepts. The first is 'intertextuality', meaning that texts always relate to other texts in the past or in the present. The second is 'interdiscursivity', and refers to discourses that overlap and interact with each other. Hence, in addition to providing an analytical toolkit in text analysis, the central concept of intertextuality and interdiscursivity is incorporated in the analysis. Intertextuality draws upon the connectedness of texts and transfer of main arguments, whereas interdiscursivity focuses upon the connections between discourses and in which ways they are drawn from one another. ${ }^{32}$ Among the various distinct strands under the umbrella of CDA, this study draws closer to Wodak's discourse approach, which has been previously used in analysing the construction of European identities. ${ }^{33}$ Wodak $^{34}$ argues that "the background of the social and political fields in which the discursive events are embedded" and thus need to be integrated into the analysis. This study tries to unmask and make transparent the kind of power relations and ideologies that have become dominant over time in the Eurosceptic discourse. CDA is the most appropriate tool for this aim, because it focusses on the deeper social forces which shape the discourse and are continuously reshaped by it. Thus, power relationships and structures affect the perception of Europe and European integration.

In sum, the approach that this study adopts is a critical approach to discourse analysis, focussing on the issues of power, hegemony and dominance in Euroscepticism in Turkey. There is still much work to be done to make Euroscepticism a conceptual and analytic unity and coherence, and it is hoped that this study can reflect and contribute to this process. 


\section{Emprical Part: Referential, Nomination and Predication Strategies}

In this section, I highlight how social actors are linguistically constructed by being named and how civil society elites refer to Europe and EU linguistically. In the following analysis, I examine the referent/nominational strategies that lie at the core of the discursive construction of civilsociety-based Eurosepticism, before proceeding to the predication strategies, namely into an analysis how certain values are attributed to these concepts. The referent/nominational strategies that lie at the heart of the discursive construction of Euroscepticism can be manifested in two main tenets.

The first important referent/nominational strategy is that Europe is, quite surprisingly, constructed as a heterogeneous entity. Leftist civil society leaders are aware of the different tendencies in the EU and, by equating the EU and the AKP (Justice and Development Party), they differentiate the left-wing tendencies in the EU. Hence, Europe and the EU are not regarded not as homogeneous entities. Nevertheless, in the following study, when expressing their scepticism towards Europe, most of the respondents were aware of the political, cultural and institutional differences within the EU. Some civil society leaders even mentioned the past wars that have been at the centre of the European project. The awareness of the non-homogeneity of the EU and Europe made the speeches more sophisticated and differentiated. I have furthermore observed that this awareness led to an adaptable approach towards Europe and the EU. If things change in the direction they support, most of the leaders are ready to soften their approach towards the EU in a pragmatic sense. Hence, they do not de-emphasise or deny the differences among the EU states. In other words, with small exceptions, the discourses show that there is an awareness of Europe's heterogeneity.

The second referential strategy refers to the in-group homogeneity in terms of ideology, but not through a Turk-European dichotomy. Several argumentative and rhetorical tools such as topoi and metaphors may be instrumental in the construction of the discourses. The first person plural pronoun "We" is important in the study of political discourse ${ }^{35}$. As Chilton and Schäffner ${ }^{36}$ argue, the first person plural (we, us, our) especially can be used by respondents to conceptualise their group identity. Leftist civil society leaders use the first person plural "We" not through a national labelling such as "We Turks", but in terms of in-group ideological homogeneity. In the case of the civil society leaders, the "We" referred more to their ideological identities, rather than an in-group homogeneity. In many utterances, it is possible to find expressions such as "We Leftists". It is therefore obvious that the selective use of the first-person plural pronoun "We" provides an opportunity for civil society leaders to perspectivate their discourse. Given the hegemonic struggles in Turkey, it is perhaps not quite surprising to use the first person plural pronoun "We Turks" to build an in-group national homogeneity.

The most important predication strategy is the negative prediction of the European colonial past. The European colonial past is harshly condemned. A theme that is particularly strong in the negative presentation strategies of the discourse is the contention that the EU only considers its own interests. This particular theme of a profit-seeking Europe is such a common predication strategy that it almost makes up a topos on its own. In describing Europe, the speakers make use of positive references such as "developed social rights" or negative, value-laden adjectives such as "colonial" or "full of paradoxes". Tables 1 gives a list of predications and nominations that were utilised in the discourses: 
Table 1: Nominations and predications of the EU/Europe in the interview texts among leftist CSO leaders

\begin{tabular}{|c|c|}
\hline $\begin{array}{c}\text { Positive } \\
\text { Nominations/Predications of the } \\
\text { EU and Europe }\end{array}$ & $\begin{array}{c}\text { Negative } \\
\text { Nominations/Predications of the } \\
\text { EU and Europe }\end{array}$ \\
\hline $\begin{array}{l}\text { - EU as an instrument for the } \\
\text { development of social } \\
\text { rights } \\
\text { - More developed worker } \\
\text { rights than Turkey } \\
\text { - Welfare state } \\
\text { - Not yet complete project } \\
\text { - Europe of labour } \\
\text { - Historic democratic } \\
\text { - } \text { struggles } \\
\text { - } \text { Remocracy } \\
\text { - Classical Music } \\
\text { - Developed human righsts }\end{array}$ & 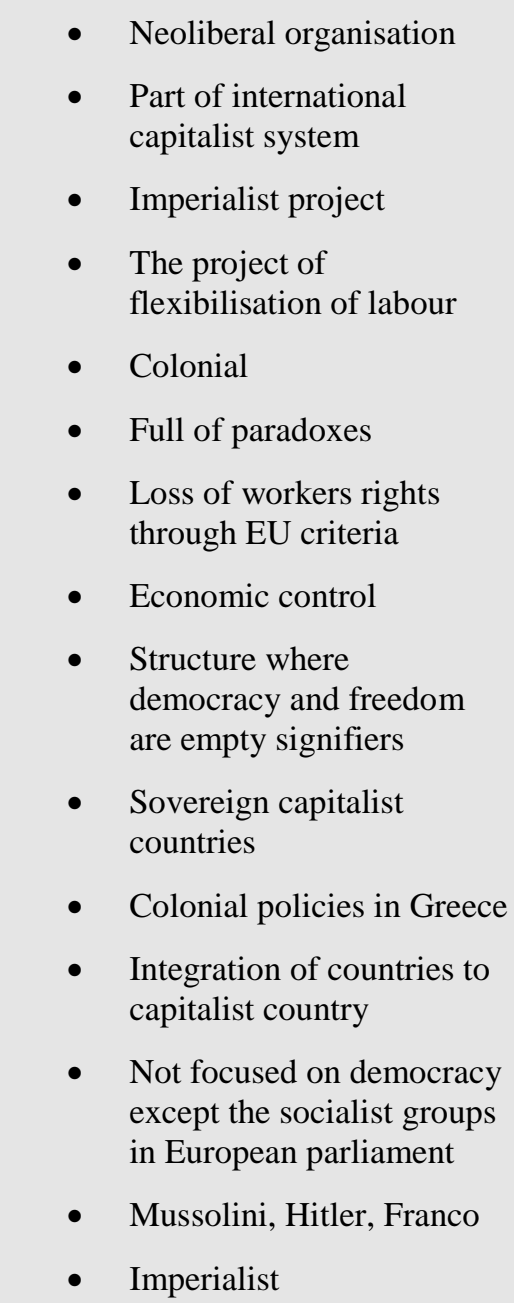 \\
\hline
\end{tabular}

\section{Argumentation Strategies}

The intense contestations over the capitalist nature of the European social and political system have surfaced in the analysis mainly among the leftist (including the leftist Alevi) discourse participants. The discursive construction of Europe as a capitalist centre is realised through two major representations of Europe: Europe as a transformative and colonial power (shared by Islamic and conservative respondents) and neoliberal Europe as the diluter of labour rights and enabler of privatisation in partnership with the AKP. These two discourses are closely interconnected and dominate in the analysed data of leftist civil society leaders. Europe is commonly represented among the leftist civil society leaders as a capitalist project that transforms the accession countries according to neoliberal policies.

To begin with, the leftist civil society leader Hüseyin Demirdüzen argues that the flow of capital is for the EU more important than the democratic values in Turkey. In other words, the 
distribution of the capital flowing from Europe to Turkey has a greater relevance for the EU than the democracy deficits in Turkey. Moreover, as the EU is not homogenous in terms of capital, it is ultimately all about economic advantages and exploitation of the Turkish market. This argumentation strategy is visible in the following excerpt:

\begin{abstract}
The EU accession process of Turkey is to a large extent about the competition of the economic forces of the European countries over the share of the Turkish market it cannot be talked about homogeneity, when it is about the shares of the German capital or French capital in Turkey; this is the most crucial aspect for both the upper class having high standards and prosperity level, and the middle class in Europe. ${ }^{37}$
\end{abstract}

Parallel to this view, for a leader of an important labour union, Ünsal Yıldiz, the EU is regarded as a project of capitalist-imperialist countries. Es1 mentions that the EU project is actually a project of the western, capitalist-imperialist countries. For him, it is not possible to say that this project is to the favour of the labour force and the workers ${ }^{38}$. Furthermore, according to Yildiz, when one analyses carefully, the EU process does not lead to democratization but to flexible work relations. The topos of making labour relations flexible is often used in the construction of Europe as a neoliberal centre as in the following excerpt:

I see the EU as a flexibilisation of the labour force, and this flexibilisation is actually a neo-liberal project, in which the labour force has no more securities, cheap labour force is spread worldwide, that the capital cancels the borders in order to obtain more profit ${ }^{39}$

It can be generally claimed that a border management (Grenzziehung in German) strategy comes into foreground among the leftist civil society leaders, as the EU is dominantly perceived as a neoliberal project, "at which the production of a plant is split into thousand parts and transferred where the labour force is the cheapest, so a border should be established at this point since it tries to deprive the security of the labour force and try further cheapen it". ${ }^{40}$ Most often, Euroscepticism increases with a referential strategy to the historical practices of Turkey with the EU that had neoliberal character. For example, Hüseyin Demirdüzen refers to the Turkish political history and the neoliberal character of the EU in the following excerpt:

The relations with the EU has reached their zenith after the military government of September $12^{\text {th }}$, which means during this time Turkey has been governed with the laws of the EU and under the control of their institutions and the neo-liberal policies have been implemented to the full. ${ }^{41}$

Demirdüzen further strengthens his argument in expressing that the EU has always supported privatisation, the mercerisation of health services and thus bolstered the sub-contracting and the unorganised state in Turkey and in other candidate countries. At the same time, for Demirdüzen ${ }^{42}$, the same Europe took an active role at the breakup of Yugoslavia. This is another referential strategy to strengthen the construction of Europe as an interest-based neoliberal organisation.

Like other leftist leaders, Kıvanç Eliaç1 $\mathrm{k}^{43}$ argues that regardless of the different opinions within it, the main policy at the foundation of the EU and during the last thirty years was the fulfilment of the requirements of the new neoliberal world order. Thus, under the perspective of neo-liberalism, public services and rights are excluded. This is stated in the following excerpt: 
In all the EU countries, ambitions and opinions that focus on education, health and social security services are excluded systematically and made ineffective in the EU. Instead, the member countries focused only with a capitalist mentality on the needs of the market, so that the requests to improve the social conditions of the labour class, to reduce the inequalities and the injustice are excluded from the EU. ${ }^{44}$

What is most striking is that the argumentation strategy of the leftist discourse points out to the harmony of AKP and neoliberal EU policies. Kıvanç Eliaçık mentions that the policy of the AKP and that of the EU follow similar principles since both are governed by neoliberal, privatisationbased and market-oriented World Bank and IMF programmes. These programmes differ from each other only with regard to their effects and results in the respective countries. Hence, while the harms and destructive effects of these policies remained limited in centrally developed European countries, they resulted in much more serious economic, political and social problems in countries like Turkey. Fahrettin Yokuş mentions the interest association between the AKP and the EU in the following:

I think that it sells the EU the empty phrase about the democratisation of Turkey very well, it makes it very trained, and the EU does so as if it would believe in this, but that, what I said before, may not be over read since there is an inseparable relation between the capital in Turkey and the EU and everything is actually determined by it. We can define it as an absolute interest association. ${ }^{45}$

According to leftist civil society leaders, in relation with the EU's radical privatisation programme, particularly the economic market programs in the fields of environment, urban development, health and social security contributed to the dramatic increase of jobs without social security, flexible and unregulated working, illegal employment, and hence poverty. Accordingly, the resulting increase of the population of workers without any social security leads to a political result, whereby dependency relationship between the AKP government and Turkish society is strengthened through the arbitrary aid provisions of the AKP, as it was the case in Europe in the 1930s and 1940s. The following excerpt exemplifies the issue:

\begin{abstract}
The victory of the AKP in the elections in the last ten years is a result of this support of the poorest layer of the society. Whilst it can be expected that traditionally the lower class and the middle class would support the social democrats, the opposite have been happening: The upper class of Turkey supported the social democrats and the others supported the AKP. And within this European accession process the AKP has implemented the neoliberal policies unconditionally and without hindrance, so basically it is in harmony with the $E U$ and although there is strong ideological and religious differences ${ }^{46}$
\end{abstract}

The excerpt above refers to the deception of the lower classes in Turkey by the AKP. ${ }^{47}$ Moreover, $\mathrm{Saraç}^{48}$ argues that it is not a coincidence that relations with the EU during the first years of the AKP have progressed very rapidly since the AKP implemented without any objection the programmes of the World Trade Organization, the International Monetary Fund and the World Bank in the frame of neoliberal economic policy. It did this along with marketisation with respect to the political elimination of markets and borders, the free movement of goods, free movement of capital and as the subsequent step the free movement of labour force. To summarise, Saraç stresses that the EU is already a part of this international capitalist system. Saraç's argumentation strategy engages in constructing the harmonisation of the AKP and the EU by predicating them as implementers of neoliberal policies. However, the argumentation excludes the social rights and struggles in the EU and concentrates only on its neoliberal character to strengthen its construction. In addition to this discursive construction the argument, through the use of topos of inequality, 
excludes Europe's social welfare system. The leftist Euroscepticism composes of a critique of the EU's neoliberal character and its negative results. The topos of inequality highlights the unequal economic and political relations, and it can be seen until today during the course of relations, that the relative old technologies and things in Europe are imposed to countries like Turkey. Furthermore the discourse distinguishes Turkey and the EU countries in expressing that countries that have recently started to develop neoliberal programmes might experience more destructive effects like unemployment, privatisation, and impoverishment.

The discourse shows a strong interdiscursivity with the recently published book Silent Violence: The AKP Years in Turkey, that problematises the synthetic articulation of Islamic politics with neoliberal capitalism during the AKP party's rule over the last ten years. The authors claim that the AKP combined neoliberal policies with Islamism:

\begin{abstract}
Islamism, indeed not an unfamiliar political stance since the foundation of Turkish Republic (1923), has provided the neoliberal pattern with an appropriate venue to develop the country. Certainly, in this articulation into neoliberal capitalism, Islamic politics have experienced a decisive transformation in relation to the state, economy, and society, thus, challenging the tension between modern, capitalist life-world and the Islamic precepts that have persisted throughout the republican history of Turkey. In its pursuit for power the AKP synthesises religious conservatism and neoliberalism. ${ }^{49}$
\end{abstract}

Nevertheless, in criticising the EU, the leftist discourse mainly does not regard the EU as a homogenous and a completed project. Leftist civil society leaders show high awareness of the fact that there are different approaches within the EU. They collaborate with the groups in the EU that defend that the EU is transforming itself into a social union, where borders are abolished and in which different countries and nations can live in peace together and where social rights and basic human rights are secured. However, because this approach is not supported by the entire European Union and by all European governments, and a strong Eurosceptic narrative is present. For example, Kıvanç Eliaçık mentions that they are advocates of this approach: they support a Europe where there are no borders anymore and where social rights are secured. The following excerpt shows this differentiated view regarding the EU:

There is also the other case; there are diverse approaches within the EU, which is
contrary to the first dimension that support a Europe with competition, with more
exploitation, with a strong European army. This approach belongs only to them and not
valid for the different groups in favour of the EU membership with different visions such as
the weakening of the influence of the military on the politics.

As is typical of the leftist discourse in Turkey on the EU, the EU is not evaluated as a fixed or completed project. This argumentation strategy does not contain the argumentative fallacy of regarding the EU as static and does not essentialise it, and indicates that the struggle for a just Europe is ongoing. To illustrate, Eliaçık stresses that they want a Europe, in which the borders are eliminated and social rights are secured, and they are dedicating their efforts to this goal and feel themselves as a part of this endeavour. ${ }^{51}$

The interview data allows us to focus on the ways in which Europe and the EU is discursively constructed in the left-wing discourse. Generally, the leftist discourse condemns the double standard against labour. Even though all the necessary regulations are made regarding trade and the free movement of capital in the Copenhagen Criteria and given high priority by the European Parliament and Commission, the leftist discourse highlights that there is very little written about the granting of union rights and labour rights that would initiate the implementation of the $19^{\text {th }}$ phrase. Mainly, leftist civil society leaders criticise the EU progress reports where sometimes only the single sentence "Nothing to report," is written. Eliaçik expresses that this 
summarises the situation to a great extent and more weight should be given to labour rights and social rights. ${ }^{52}$ Eliaçık underlines his wish that the EU should become a peace project, not an imperialist centre in the following excerpt:

Of course it is true that the EU has not achieved its final form. There are some negative samples for it; for some the EU should be a competitive market, establish its own army and intervene in conflicts, participate in combats in different locations. We are against this. We want that the EU becomes a good willed peace project, a place where social rights are secured, but the EU wants to become an imperialist centre. At the same time there are those, who work toward that it becomes a capitalist market state, which is based on the further exploitation of the worker, low wages. These are points which we criticise. ${ }^{53}$

The above excerpt from a left-wing civil society elite does not essentialise the EU and accepts its dynamic nature. However it criticises the present situation of the EU. The designation of Europe as an imperialist centre through exploitation is a common argumentative strategy in the discourse of left-wing civil society leaders. This is realised mainly through the topos of imperialism and of exploitation representing the EU as a transformative neoliberal power that acts according to its own interests. Baki Çınar mentions the importance of the leftist parts in the EU in the following:

We only hear that the left, socialist, communist representative in the EU parliament notify Turkey on diverse platforms their opinions regarding the deficits, these problems, but also know that not the left groups have the word in the EU, but the capital ${ }^{54}$

In a similar vein, according to Ünsal Yıldız, the EU project is at the same time the internalisation of the neoliberal transformation programme. He argues that one of the most important justifications for the losses of many rights for workers in Turkey has been the implementation of the EU standards. If one looks at the EU standards regarding work relations, they are reorganised in a more flexible and insecure way. Ünsal Yıldız mentions that the conditions in Turkey in terms of the labour rights twenty years ago were much more extensive, and today Turkey has departed from these rights. Viewed in this light, he stresses that the EU story has not brought many positive things for Turkey. ${ }^{55}$ Semsa Özar ${ }^{56}$ and Baki Çınar ${ }^{57}$ mention that vis-à-vis the extension of workers' rights progress has not been achieved in hardly any of the requests. Work life in Turkey is still regulated by the laws from the 12 September fascist coup. Whilst the EU recommended and supported Turkey to eliminate the remnants of the 12 September laws and to end the military tutorship, when it came to working life, when it was about to make legal regulations in order to allow for stronger labour organisation, these issues were almost never included in the agenda. This is also related to the issue that the EU is a capitalist project, with countries integrated into this system according to the needs of the capital. The rights and interests of the workers are in the background. Furthermore, in the leftist discourse, the common referential and argumentation strategy is to equalize the EU with the IMF, the World Bank and the USA as can be observed in the following excerpts:

Purely politically, Europe is not the cradle of democracy or so. It accommodates with the NATO, the IMF, the World Bank; its present economic control has serious antidemocratic, anti-freedom trends in itself. ${ }^{58}$

There is a regime, an economic regime, which all these, the USA, the EU, the World Bank, the IMF try to impose on the world. We think that this is the real target in transforming Turkey to include it to the system. I think that this is a domination which from the sight of all these countries boils down to export the neo-liberal production relation called the new 
face of capitalism. When this is once accepted a truth, we do not need to discuss other details. ${ }^{59}$

In the first excerpt above, Necdet Saraç argues that Europe is not the cradle of democracy and sees it similar to the capitalist institutions such as the IMF and the World Bank. This is a very common argumentation strategy that uses the topos of regime or system to disregard the differences among these institutions and to construct them as a part of a system. The excerpt above is an important case in which discussions on capitalist Europe lead to the interdiscursivity with Marxist and neo-Marxist thinkers. According to labour union leader Baki Çınar, ${ }^{60}$ the IMF founded the World Bank in order to economically safeguard the rights and interests of the imperialist bloc around the USA and particularly to integrate Third World countries into this process. Accordingly, particularly after the collapse of the Eastern Bloc, NATO has tried to be integrated into this system with military operations. Therefore, the EU is not an organization that is independent from this. Çınar stresses that the AKP has become a partner of the policies implemented by the imperialist block around the USA, particularly with the intensification of the crisis experienced by capitalism.

There are no differences between these two with respect to this foreign policy dimension. When we look at the close past, we will see that nearly the whole EU was together with the USA as a party of the intervention to Iraq. It was nearly the same situation regarding the policy against Syria, there is no difference between the politics of the EU and the USA with respect to Iran. ${ }^{61}$

In this sense, Çinar mentions that the EU supports the politics of the USA fully. According to him, it can be accepted that there is a difference regarding the respective democracy cultures, but there is, according to their perception, no difference between the imperialism of the USA and the imperialism of the EU in terms of the politics implemented against countries like Turkey.

The leftist civil society leaders, Semra Ocak and Semsa Özar, add to the discussion in arguing that the EU can function at the disadvantage of the weak states, as was the case in Greece:

Particularly, as it has been seen during crisis periods, in a form, in which countries like Germany, France and England have imposed their own decisions to the other countries. Thus the free decisions of countries are made invalid within the course of the process as it was the case in the sample of Greece. ${ }^{62}$

The EU have initiated a coup without respecting the will of the Greek people with assignment from outside. ${ }^{63}$

As can be observed in the excerpts above, the leftist leaders argue that the policy of the EU against Greece was unjust and that the case of Greece gave many lessons to countries such as Turkey. Choosing the verb "impose" can be interpreted as the discursive strategy of mitigation whereby the speaker "mitigates the illocutionary force" of a negative utterance. ${ }^{64}$ In an interdiscursive fashion to European communists, the EU-Greece relations are interpreted in a way where the EU's attitude towards Greece is unjust. In a similar vein, Baki Çınar thinks that the policy of the EU against Greece is unfair. He thinks that the policy of the EU, particularly of the bloc around Germany, against Greece is a complete imperialist, subjugating policy:

When one pays attention on it, it is enforced based on primarily the limitation of the existing rights of the population, the worker in order for that the balance, economic 
balance in Greece can be restored again. There were regulation for serious cut offs from the wages, people are compulsory retired and are being still so. If one looks at the larger image, there is no difference. Anywhere in the world, at any time the case, the argument of the world domination of capital block is at overcoming crisis cutting primarily the rights of the workers, limiting the existing, gained, used rights of the workers. ${ }^{65}$

As can be observed in the following, this logic also tried to implement similar applications in Greece. What is most striking at this point for the leftist respondents is that then the Greek people did not surrender to the process. For example, Çınar mentions that Greece has shown great resistance in holding firm to their own traditions and cultural roots against the subjugation politics of the EU. The meaningful thing in the issue for Çınar is this fact. ${ }^{66}$ Semsa Özar mentions that the economic crisis diminished the image of the EU. When she looks at the EU from Turkey, she sees the following:

Germany has established its authority there, countries like Greece and Spain, though they have made important changes to their economy, that every day it is to be seen on TV how retired people collect this or that from wastes or that the one or the other happens, begun to fade the enthusiasm in the eyes of the people. ${ }^{67}$

With a rather pessimistic attitude, Ünsal Y1ldiz adds to the discussion in stating that the EU cannot develop to desired direction in the following excerpt:

But as far as we can see there is not a strong class consciousness among the workers in these countries, due to the high national income based on the imperialist grounds of Europe in the world. Accordingly, to live in a developed country has its advantages in the economic sense. And in this view their class problems are not that much in the foreground as a result of these advantages. It seems to be difficult that the EU might be transformed to the favour of the workers. ${ }^{68}$

However, Ünsal Yildız thinks that the reactions of the workers in Italy, Spain, Greece and Portugal against the crisis in these countries are very important. He argues that with the crisis, the workers in Europe started to remember the presence of classes again, which they had abandoned a long time ago, which is a very pleasant development. Nevertheless, due to the severe crisis in Greece, to think that this could transform the EU does not seem to be politically realistic ${ }^{69}$

In a similar vein, Baki Çınar predicates the EU as a capitalist project. He assesses it as a structure that was initiated with the steel union, established by the European upper class, particularly in France and Germany, in order protect the capital and to ensure that it remains strong and competitive primarily against the bloc around America and the Asian bloc around China and Japan. This argumentation strategy is observed in the following excerpt:

To build an economic block in Europe was the main aim, and took its late shape with the political integration. The EU is a structure, whereby the requests and expectations of people, freedom requests of ethnic groups in underdeveloped countries are kept in the background in general. Nevertheless, the project is though presented such. ${ }^{70}$

This argumentative strategy suggests a discrepancy between real world practices of the EU and its rhetoric presented as its basic philosophy. Çınar adds the Customs Union Agreement to the discussion. Since 1995 Turkey has undersigned to the most important part of capitalist European project, the Customs Union Agreement. According to him, this has made Turkey from the 
perspective of the capitalists somehow a member of the EU by transforming it into a market. Today Turkey is integrated into the process pursuant to the expectations of the capitalists. Therefore, he concludes that the discussion about whether Turkey should become a member or not is ultimately not a historical importance for them.$^{71}$

An Alevi civil society leader expresses criticism of the Customs Union and a serious expression regarding the exploitation rhetoric of the EU in the following excerpt:

The first is that the EU will exploit you until the end and accept you then. Everything happened as wanted by the EU, the Customs Union is achieved, and the market is secured. Why should it now undertake the burden of this population? It has cheated against Turkey everywhere it could, thanks to Tansu Ciller. And then, this woman comes to Turkey and shouts on TV "We are a full member of the EU." I experienced the greatest shame, the greatest anger of my life that time. ${ }^{72}$

Bermek argues that Turkey is already in the EU economically, as the majority of imports came from EU, but it cannot sell anything. Bermek ${ }^{73}$ mentions this in the following: "I mean, we sell them spare parts, but if this will be accepted or not depends on Germany. We here are workers, their temporary workers. For Europe, everything is fine, why should it accept us, what shall it do with us". He thinks that the EU has a double moral standard, meaning not only anti-imperialist worldview but also double standard resolutions in the EU plays a vital role in the Euroscepticism.

The leftist discourse combines the democracy culture and class struggles in Europe. One leader mentions that an important detail is the centuries-long class warfare in continental Europe that led to the existing democracy culture on the basis of deep roots. The obtainment of granted or existing rights is the result of the struggle of the working class. It cannot be overlooked that today these rights are protected and have been extended. This is an argumentation strategy that must be underlined as a positive attitude towards the EU in the leftist discourse in general. Additionally, Yildiz ${ }^{74}$ argues that the guarantee of democratic rights for Turkey is not only dependent on joining the EU, and that these should be seen as values that the citizens of the country deserve. For him, it is possible for Turkey to remain out of the EU. He argues that the negotiations did not bring democracy to Turkey. According to Y1ldiz ${ }^{75}$, the negotiations have carried out, but democracy has contracted in Turkey: prisons are $110 \%$ more full, anyone who objects or speaks out - including journalists and writers - is imprisoned:

Democratisation it is not about whether we are accepted to the European Union or not, but about how the level of the basic rights in our society will be, and that this actually is related with our fight and has nothing to do with whether we get an EU member or not. ${ }^{76}$

Moreover, leftist CSO leaders stress the importance of internal dynamics and show distrust in the EU because of its neoliberal policies. Leftist Euroscepticism emphasises that change made through internal and local dynamics rather than through external influences results in real change. According to leftist civil society discourse, the EU is a project that is based on the trends of the world system and that a country alone cannot achieve modernisation and its development through it as these are issues that can be realised with domestic dynamics, and the domestic dynamics in Turkey are not sufficiently mature:

There is increasing number of people, for whom the membership of Turkey to the EU is not a fate for Turkey and that Turkey overcomes the social struggle with its own social dynamics. $^{77}$ 
The economic development is to be achieved through domestic dynamics and neither a hostility nor and admiration against the EU is necessary ${ }^{78}$

Nevertheless, there are more optimistic leftist labour union leaders. A leftist civil society leader argues that the EU membership would be beneficial for the enhancement of social and labour rights and stresses that the EU accession process could be used as a tool for the improvement of the social rights and labour rights because these rights are much better established and secured in the $\mathrm{EU}^{79}$. For Faruk Büyükkocak, the EU has its own standards regarding working life in other countries and expectations from the EU regarding working life are not fulfilled because of the AKP. He states that although they had told them that this issue had been sent to the ILO, they obtained no reaction against the behaviour of a government that is not fulfilling the European social preconditions ${ }^{80}$.

In terms of health policy, a leftist civil society leader argues that impossible to talk about a EU health policy:

\begin{abstract}
Developed EU countries have different health policies, as the northern European countries their social health policy or England, central European countries have a market economy that nearly all these countries have begun to resemble themselves with the marketisation of the system, liberal, pro-privatisation programmes. Turkey integrates itself by setting over to the insurance model, or the family physician system, or the privatisation of hospitals and public-private associate enterprises with regard to the purchase of health services much faster than in other fields. ${ }^{81}$
\end{abstract}

Moreover, a human rights organisation leader argues that the human rights organisations in the EU under pressure:

\begin{abstract}
Many of them are being closed. Their expectations are not fulfilled, either. These are countries that constitute the union, and they mean that the organizations should care themselves to survive, they are not supported by the governments. We are giving the EU much money for that something results from there. Many of the organizations in the EU are dissolved. The budgets have been shrunken. This is the case in Germany, in Denmark, in Sweden. The attitude of the governments, of the EU is bad. It is treated so as if this weren't that important. ${ }^{82}$
\end{abstract}

\title{
Conclusion
}

Y1ldırım ${ }^{83}$ discovered that in the domain of Turkish labour confederations "it is the ideological configurations, the nature of their relations with the state and the EU's attitudes to Turkish membership that largely influence the Turkish peak organizations' approach to the EU". The section supported this argument to a great extent by showing that the main leftist CSO leaders use the argumentation strategy of the neoliberal EU. Compared to business organisations, a large part of the trades unions have a cautious approach towards European integration. Notwithstanding the fact that conservative trade union leaders show a tendency towards Eurocynicism, other leftist CSO leaders draw on their ideological tendencies in evaluating the EU and the European integration process, and view the EU a locus of free trade ideology. However, leftist trade union leaders stress that they tend to evaluate it positively when they observe an advancement of the labour rights, which was not the case until now in Turkey. Accordingly, trades unions and social rights have usually been seen as "the step child of the EU integration process"

Generally, the leftist leaders do not perceive the EU process strategically or as a political opportunity structure to gain influence ${ }^{85}$, but predominately more ideologically, as the spread of neoliberal free market policies that create an anti-labour environment. ${ }^{86}$ Leftist leaders are more 
likely to support European integration if they believe and see that it will result through an ideological change in more benefits for labour than those available at the national level. Generally, the discourse includes criticisms regarding the negative economic results of the Customs Union Agreement and that it was unrealistic to expect the EU to improve labour rights and union freedom during the accession process. Leftist CSO leaders argue that the EU in itself is an organisation within a capitalist system, but, at the same time, they mainly accept that the social | 68 welfare state, democracy and rule of law are created by struggles of labour and constitute the main pillars of the EU. However, the accession process showed that the EU has become less and less attentive to social rights. Accordingly, they want to have close relations with European labour to change the direction of the EU.

The study of Euroscepticism so far has included mainly two specific areas: party-based Euroscepticism and public Euroscepticism. What this study aimed to articulate is the need to focus on civil society in addition to national party systems and public opinion, as non-party actors have an important function in shaping the general EU discourse ${ }^{87}$. Moreover, analysis of civilsociety-based Euroscepticism, of the way it develops and the content of the grievances it addresses to European integration and the EU are vital to a sound diagnosis of the crisis of confidence faced by the EU. In Turkey, as well civil-society based argumentative strategies on the EU are also operative and influential.

The leftist discourse condemns that the double standard against labour. They underline the wish that the EU would become a peace project, not an imperialist centre. Left-wing civil society leaders do not essentialise the EU and accept its dynamic nature, but they criticise the present situation of the EU. To sum up, leftist CSO leaders base their Eurosceptic arguments mainly on ideological grounds rather than strategic factors. Nevertheless, in their argumentations they regard the EU as a heterogonous entity that is open to dialectical change. Hence, The radical left is not Eurorejectionist but Eurosceptical due to their opposition to the centrality of neo-liberal policies in European integration.

The following study fills a gap which Mair ${ }^{88}$ argues: He claims that the literature mainly focusses on "standardises quantitative variables that can be used directly in highly abstract crossnational research... We need to know more about how Europe actually plays in national political discourse, as well as about the way in which it is conceived." Besides enlarging the research field, this study contributes to the development of Euroscepticism research in suggesting that traditional categories and established theories of public and elite attitudes towards European integration fell short in explaining the Euroscepticism in non-EU countries. This leads to the conclusion that we should supplement the traditional categories and resolve contradictions by using a discursive approach.

\section{Notes}

\footnotetext{
${ }^{1}$ Fuat Keyman and Ahmet İçduygu, "Globalization, Civil Society and Citizenship in Turkey: Actors, Boundaries and Discourses." Citizenship Studies 7 (2003): 221

${ }^{2}$ Romain Pasquier and Julien Weisbein, "L'Europe au microscope du local. Manifeste pour une sociologie politique de l'intégration communautaire." Politique européenne 12 (2004): 13

${ }^{3}$ Hayat Kabasakal and Muzaffer Bodur, "Leadership and Culture in Turkey: A Multifaceted Phenomenon." in Culture and Leadership Across the World: The Globe Book of In-Depth Studies of 25 Societies, edited by Chhokar Jagdeep, Felix Brodbeck and Robert House. London: Routledge(2007): 835-875.

${ }^{4}$ It is largely believed that the EU accession process has been a crucial tool in the democratisation and modernisation of the country. Nevertheless, many civil society leaders question this assertion.

${ }^{5}$ Ruud Koopmans, "Who Inhabits the European Public Sphere? Winners and losers, supporters and opponents in Europeanized public debates." European Journal of Political Research 46(2007): 183-210.

${ }^{6}$ Thomas Diez, "Speaking Europe: The Politics of Integration Discourse." Manuscript for Journal of European Policy 6 (1999):4.
} 
${ }^{7}$ To illustrate, as Henderson (2001:4) suggests for the post-communist states, opposing attitudes towards the EU-membership are associated with a scepticism to modernisation and post-communist economic reform. Hence, it is more common among the losers of the transformation process.

${ }^{8}$ Gary Marks and Marco Steenbergen, 2004. European Integration and Political Conflict, (Cambridge University Press: Cambridge 2004)

${ }^{9}$ Donatella Della Porta and Manuela Caiani, Social Movements and Europeanization, (Oxford University Press: Oxford Della Porta 2009)

${ }^{10}$ Patrick Chamorel, "Anti-Europeanism and Euroskepticism in the United States." in Hard Power, Soft Power and the Future of Transatlantic Relations, edited by Thomas L. Ilgen. London: AshgateChamorel (2006): 163-193

${ }^{11}$ Paul Hainsworth, Carolyn O’Brien and Paul Mitchell, "The Politics of Euroscepticism on the French Right." in Euroscepticism: Party Politics, National Identity and European Integration, edited by Robert Harmsen and Menno Spiering, European Studies 20, (Amsterdam: Editions: Rodopi, 2004), 37-58

${ }^{12}$ Turkey can quite be seen as similar to the French case in terms of the focus of Kemalist rhetoric on the primacy of the nation-state and national unity. A certain meaning of Euroscepticism is associated with Mustafa Kemal Atatürk as the leader of Turkish nation parallel to as in the association of the French Euroscepticism with another important leader in twentieth century politics: Charles de Gaulle.

${ }^{13}$ Susan Milner, "For an Alternative Europe: Euroscepticism and the French Left Since the Maastrict Treaty." in Euroscepticism: Party Politics, National Identity and European Integration, edited by Robert Harmsen and Menno Spiering, European Studies 20. (Amsterdam: Rodopi, 2004), 59-81

${ }^{14}$ Paul Taggart, and Aleks Szczerbiak, "Theorising Party-Based Euroscepticism: Problems of Definition, Measurement and Causality." SEI Working Paper No. 69, (2004)

${ }^{15}$ Lauren McLaren and Meltem Müftüler-Bac,. "Turkish Parliamentarians' Perspectives on Turkey's Relations with the European Union." in Turkey and European Union, Domestic Politics, Economic Integration and International Dynamics, edited by Ali Carkoglu and Barry Rubin, (London: Frank Cass, 2003), 195-218

${ }^{16}$ Ümit Cizre,. "Problems of Democratic Governance of Civil-Military Relations in Turkey and the EU Enlargement Zone", European Journal of Political Research, 43, 1, (2004):107-125.

${ }^{17}$ Gamze Avc1, "Turkish Political Parties and the EU Discourse in the Post-Helsinki Period: A Case of Europeanization." in: Turkey and European Integration: Accession Prospects and Issues, edited by Nergis Canefe and Mehmet Ugur. ;(London and New York: Routledge, 2004), 194-215

Gamze Avc1, "The Justice and Development Party and the EU: Political Pragmatism in a Changing Environment." South European Society and Politics 16, 3, (2011.): 409-421

Seckin Baris Gülmez, "The EU Policy of the Republican People's Party: An inquiry on the opposition party and Euro-skepticism in Turkey." Turkish Studies 9,3, (2008): 423-436

Can Büyükbay, Euroskeptizismus in der Türkei. Die Republikanische Volkspartei (CHP) und die Nationalistische Bewegungspartei (MHP) im Vergleich. (Saarbrücken: VDM Verlag, 2010)

Can Büyükbay,. "Patterns of Party-Based Euroscepticism in Turkey." International Review of Turkish Studies 1,2, (2011): 78-114.

Can Büyükbay, "Gründe und Ausformungen des Euroskeptizismus bei der Republikanischen Volkspartei (CHP) und bei der Nationalistischen Bewegungspartei (MHP)." European Journal of Turkish Studies. (2011) Retrieved: http://ejts.revues.org/index4370.html

Can Büyükbay,: "Limited Autonomy of the Civil Society and the Misuse of the EU Accession Process." Centre for Policy Analysis and Research on Turkey 1, 5, (2012): 6-10. Retrieved (http://researchturkey.org/?p=1528).

Can Büyükbay and Adis Merdzanovic, "Comparing Euroscepticism in Turkey and Bosnia." (Presented at the $19^{\text {th }}$ International Conference of Europeanists, Council for European Studies, 22-24 March 2012, Boston.)

${ }^{18}$ Hakan Y1lmaz, "Euroscepticism in Turkey: Doubts, Anxieties and Fears of the Turkish Public

Concerning Europe and the European Union." (Open Society Institute: Istanbul. 2003)

Çigdem Kentmen, "Determinants of Support for EU Membership in Turkey: Islamic Attachments, Utilitarian Considerations and National Identity." European Union Politics 9, 4, (2008): 487-510.

${ }^{19}$ Sedef Eylemer and İlky Taş, "Pro-EU and Eurosceptic Circles in Turkey." Journal of Communist Studies and Transition Politics 23,4, (2007): 561-577.

${ }^{20}$ Engin Yıldırım, "Turkish Labour Confederations and Turkey's Membership of the European Union." Economic and Industrial Democracy, 29, 3, (2008): 362-387. 
${ }^{21}$ John Fitzgibbon, "Citizens Against Europe? Civil Society and Eurosceptic Protest in Ireland, the United Kingdom and Denmark." Journal of Common Market Studies 51, 1, (2013): 105-121.

${ }^{22}$ The White Paper on European Governance (2001:14)

${ }^{23}$ For practical reasons, I have avoided a narrow usage of civil society, which would have excluded many important actors from the analysis.

| $70 \quad{ }^{24}$ The CONECCS-EU Civil Society Database (2011)

${ }^{25}$ Fuat Keyman and Ahmet İçduygu, "Globalization, Civil Society and Citizenship in Turkey: Actors, Boundaries and Discourses." Citizenship Studies 7 (2003): 219-234

${ }^{26}$ I consider knowledge produced from the interview to be pragmatic because "Today, the legitimacy question of whether a study is scientific, or whether it leads to true knowledge, tends to be replaced by the pragmatic question of whether it provides useful knowledge. Good research is research that works... There is an insistence in pragmatism that ideas and meanings derive their legitimacy from enabling us to cope with the world in which we find ourselves" (Kvale, Brinkmann 2009:56). Hence, interviewing is interpreted as a craft, as a knowledge-producing activity and as a social practice (Kvale, Brinkmann 2009:17).

${ }^{27}$ Consequently, carrying the direct experiences and their influences on the perception of the elites may have contributed greatly to modelling and theorising endeavours in Euroscepticism field.

${ }^{28}$ Ruth Wodak, "The Discourse-historical Approach." in Methods of Critical Discourse Analysis, edited by Ruth Wodak and Michael Mayer (London: SAGE, 2001), 63-95

${ }^{29}$ Thomas Diez, "Speaking Europe: The Politics of Integration Discourse.” Manuscript for Journal of European Policy 6,4(1999):1-25.

${ }^{30}$ Norman Fairclough and Ruth Wodak, "Critical Discourse Analysis." in Discourse as Social Interaction, edited by Teun A. van Dijk. (London: SAGE, 1997) 258-284

${ }^{31}$ Gilbert Weiss and Ruth Wodak, "Theory and Interdisciplinarity in Critical Discourse Analysis. An Introduction." in Theory and Interdisciplinarity in Critical Discourse Analysis, edited by Gilbert Weiss and Ruth Wodak (London: Palgrave Macmillan, 2003) 1-34

${ }^{32}$ Ruth Wodak,. "The Discourse-historical Approach." in Methods of Critical Discourse Analysis, edited by Ruth Wodak and Michael Mayer. (London: SAGE, 2001) 63-95

${ }^{33}$ M. Krzyzanowski and F. Oberhuber, (Un)doing Europe: Discourse and Practices in Negotiating the EU Constitution. (Brussels: P.I.E.-Peter Lang, 2007)

${ }^{34}$ Wodak, Ruth.. "The Discourse-historical Approach." in Methods of Critical Discourse Analysis, edited by Ruth Wodak and Michael Mayer. (London: SAGE, 2001) 63-95

${ }^{35}$ Disk Van, A.Teun, "On the Analysis of Parliamentary Debates on Immigration." in The Semiotics of Racism, Approaches to Critical Discourse Analysis, edited by Martin Reisigl and Ruth Wodak. (Vienna: Passagen Verlag, 2000): 85-103

${ }^{36}$ Paul Chilton and Christina Schäffner. "Discourse and Politics." in Discourse as Social Interaction, edited by Teun A. van Dijk. Volume 2, Discourse Studies: A Multidisciplinary Introduction. (London: Sage, 1997) 206-230

${ }^{37}$ Hüseyin Demirdüzen, Board Member, Turkish Medical Association, (İstanbul, 30 January 2012: 43-48)

${ }^{38}$ Ünsal Yıldız, President, Eğitim-Sen, Education Trade Union, (Ankara, 6 April 2012): 1177-1180

${ }^{39}$ Semra Ocak, Head of Istanbul Section, TMOBB CMO, Chamber of Environmental Engineers, (24 January 2012 ):80-83

${ }^{40}$ Semra Ocak: $107-110$

${ }^{41}$ Demirdüzen: 103-107

${ }^{42}$ Demirdüzen:161-166

${ }^{43}$ Kıvanç Eliaçık, Head of International Relations Department (DISK), Revolutionary Labour Unions Confederation of Turkey, (İstanbul, 24 February 2012, 135-141)

${ }^{44}$ Kıvanç Eliaçık:185-201

${ }^{45}$ Fahrettin Yokuş, General Secretary, Kamu-Sen, Turkish Public Workers Labor Union, (Ankara, 10 April 2012, 1478-81)

${ }^{46}$ Necdet Saraç, Deputy President, ABF, Alevi-Bektaşi Federation, (Ankara, 10 April 2012: 203-211)

${ }^{47}$ Yalman stresses that "analysing the state transformation that Turkey has been experiencing under the AKP governments requires a detailed look at the party`s skilful manipulation of neoliberalisation with Islamisation in building its hegemonic opposition to the established Republican regime." Yalman, Galip.. "Politics and Discourse under the AKP's Rule: The Marginalisation of Class-Based Politics, Erdoğanisation, and Post-Secularism." In Silent Violence: Neoliberalism, Islamist Politics and the AKP Years in Turkey, edited by Simten Cosar and Gamse Yücesan-Özdemir (Ottawa: Red Quill Books, 2012)

${ }^{48}$, Saraç:142-171 
${ }^{49}$ Coşar, Simten and Gamze Yücesan-Özdemir, eds. 2012. Silent Violence: Neoliberalism, Islamic Politics and the AKP years in Turkey. Ottawa: Red Quill Books (Cosar and Özdemir 2012:11)

${ }^{50}$ Eliaçik: 643-650

${ }^{51}$ Eliaçik: 650-662

${ }^{52}$ Eliaçık:662-670

${ }^{53}$ Eliaçı: 670-677

${ }^{54}$ Baki Çınar, General Secretary, KESK, Confederation of Public Workers' Unions, (Ankara, 10 April 2012: 1475-78)

${ }^{55}$ Ünsal Yildız:1180-1200

${ }^{56}$ Board member, DISA, (Istanbul. 20 May 2012: 630)

${ }^{57}$ Baki Çınar: 1020

${ }^{58}$ Saraç: $1338-1340$

${ }^{59}$ Baki Çınar: 1230-1240

${ }^{60}$ Baki Çınar: $1340-1350$

${ }^{61}$ Baki Çınar: 930-935

${ }^{62}$ Ocak: $117-123$

${ }^{63}$ Özar: 677-680

${ }^{64}$ Martin Reisigl and Ruth Wodak, The Semiotics of Racism, Approaches to Critical Discourse Analysis (Vienna: Passagen Verlag, 2000): 81.

${ }^{65}$ Çınar:1602-1609.

${ }^{66}$ Çınar:1435-1445.

${ }^{67}$ Semsa Özar:1367-70.

${ }^{68}$ Ünsal Yildız:403-409.

${ }^{69}$ Ünsal Yildız:1200-1216.

${ }^{70}$ Çınar: $1400-1410$

${ }^{71}$ Çınar: $1410-1415$.

${ }^{72}$ Doğan Berkmek, President, AVF, Federation of Alevi Foundations, (İstanbul, 27 February 2012, 817 822)

${ }^{73}$ Bermek:822-831.

${ }^{74}$ Ylldiz: 576-600

${ }^{75}$ Ylldiz: 610-614

${ }^{76}$ Ylldiz: 603-606

${ }^{77}$ Ocak: $87-90$

${ }^{78}$ Hulusi Zeybek, board member (IHD), Human Rights Association, (İstanbul, 23 January 2012 :38-43)

${ }^{79}$ Eliaçık:640-644

${ }^{80}$ Faruk Büyükkocak, President of Region 1 TURK-IS, Confederation of Turkish Trade Unions, (İstanbul, 9 March 2012: 976-983)

${ }^{81}$ Zeybek:171-180

${ }^{82}$ TIHV, Turkish Human Rights Foundation, General Secretary,( Ankara, 12 April 2012:1380-1387)

${ }^{83}$ Engin Yıldırım, "Turkish Labour Confederations and Turkey's Membership of the European Union." Economic and Industrial Democracy, 29, 3, (2008):362.

${ }^{84}$ Seckin Baris Gülmez, "The EU Policy of the Republican People's Party: An inquiry on the opposition party and Euro-skepticism in Turkey.” Turkish Studies 9, 3, (2008): 423-436.

${ }^{85}$ Tanja A Börzel and Thomas Risse, "Conceptualizing the Domestic Impact of Europe." in The Politics of Europeanization, edited by Kevin Featherstone and Claudio M. Radaelli. (Oxford: Oxford University Press, 2003) 63

${ }^{86}$ Richard Hyman,. "The Europeanization - or the Erosion - of Industrial Relation." Industrial Relations Journal 32, 4, (2001): 280-94.

${ }^{87}$ John Fitzgibbon,. "Citizens Against Europe? Civil Society and Eurosceptic Protest in Ireland, the United Kingdom and Denmark." Journal of Common Market Studies 51, 1, (2013): 105

${ }^{88}$ Peter Mair, "Political Parties and Party Systems." In Europeanisation: New Research Agendas, edited by Paolo Graziano and Maarten P. Vink. (Houndmills: Palgrave Macmillan, 2007), 162

\section{Bibliography}

Avc1, Gamze. 2004. "Turkish Political Parties and the EU Discourse in the Post-Helsinki Period: A Case of Europeanization." Pp. 194-215 in: Turkey and European Integration: Accession Prospects and Issues, edited by Nergis Canefe and Mehmet Ugur. London and New York: Routledge. 
Avc1, Gamze. 2011. "The Justice and Development Party and the EU: Political Pragmatism in a Changing Environment." South European Society and Politics 16(3): 409-421.

Avc1, Gamze. 2011. "The Nationalist Movement Party's Euroscepticism: Party Ideology Meets Strategy." South European Society and Politics 16(3): 435-447.

Börzel, Tanja A. and Thomas Risse. 2003. "Conceptualizing the Domestic Impact of Europe." Pp. 55-80 in The Politics of Europeanization, edited by Kevin Featherstone and Claudio M. Radaelli. Oxford: Oxford University Press.

Büyükbay, Can. 2010. Euroskeptizismus in der Türkei. Die Republikanische Volkspartei (CHP) und die Nationalistische Bewegungspartei (MHP) im Vergleich. Saarbrücken: VDM Verlag.

Büyükbay, Can. 2011a. "Patterns of Party-Based Euroscepticism in Turkey." International Review of Turkish Studies 1(2): 78-114.

Büyükbay, Can. 2011b "Gründe und Ausformungen des Euroskeptizismus bei der Republikanischen Volkspartei (CHP) und bei der Nationalistischen Bewegungspartei (MHP)." European Journal of Turkish Studies. Retrieved: http://ejts.revues.org/index4370.html

Büyükbay, Can. 2012a: "Limited Autonomy of the Civil Society and the Misuse of the EU Accession Process." Centre for Policy Analysis and Research on Turkey 1(5): 6-10. Retrieved (http://researchturkey.org/?p=1528).

Büyükbay, Can and Adis Merdzanovic. 2012b "Comparing Euroscepticism in Turkey and Bosnia." Presented at the $19^{\text {th }}$ International Conference of Europeanists, Council for European Studies, 22-24 March 2012, Boston.

Çarkoglu, Ali. 2003a. "Who Wants Full Membership? Characteristics of Turkish Public Support for EU Membership." Turkish Studies 4(1): 171-194.

Chamorel, Patrick. 2006. "Anti-Europeanism and Euroskepticism in the United States." Pp. 163193 in Hard Power, Soft Power and the Future of Transatlantic Relations, edited by Thomas L. Ilgen. London: Ashgate.

Chilton, Paul and Christina Schäffner. 1997 "Discourse and Politics." Pp. 206-230 in Discourse as Social Interaction, edited by Teun A. van Dijk. Volume 2, Discourse Studies: A Multidisciplinary Introduction. London: Sage.

Cizre, Ümit.2004. "Problems of Democratic Governance of Civil-Military Relations in Turkey and the EU Enlargement Zone", European Journal of Political Research, Vol:43, No:1. 107-125.

Coşar, Simten and Gamze Yücesan-Özdemir, eds. 2012. Silent Violence: Neoliberalism, Islamic Politics and the AKP years in Turkey. Ottawa: Red Quill Books.

Della Porta, Donatella. 2006. "The Anti-Globalization Movement and the EU: Critics of Europe."

Paris: Notre Europe, policy paper no. 22.

Della Porta, Donatella and Manuela Caiani. 2009. Social Movements and Europeanization. Oxford: Oxford University Press.

Diez, Thomas. 1999. "Speaking Europe: The Politics of Integration Discourse." Manuscript for Journal of European Policy 6(4): 1-25.

European Commission. 2001. "White Paper on European Governance." Official Journal of European Communities C 287(1): 1-29.

Fairclough, Norman and Ruth Wodak. 1997. "Critical Discourse Analysis." Pp. 258-284 in Discourse as Social Interaction, edited by Teun A. van Dijk. London: SAGE.

Fitzgibbon, John. 2013. "Citizens Against Europe? Civil Society and Eurosceptic Protest in Ireland, the United Kingdom and Denmark." Journal of Common Market Studies 51(1): 105-121.

Gülmez, Seckin Baris. 2008. "The EU Policy of the Republican People's Party: An inquiry on the opposition party and Euro-skepticism in Turkey." Turkish Studies 9(3): 423-436.

Eylemer, Sedef and İlky Taş. 2007. "Pro-EU and Eurosceptic Circles in Turkey." Journal of Communist Studies and Transition Politics 23(4): 561-577.

Güneş-Ayata, Ayse. 2003. "From Euro-scepticism to Turkey-scepticism: changing political attitudes on the European Union in Turkey." The Journal of Southern Europe and the Balkans 5(2): 205222.

Hainsworth, Paul, Carolyn O'Brien and Paul Mitchell. 2004. "The Politics of Euroscepticism on the French Right." Pp. 37-58 in Euroscepticism: Party Politics, National Identity and European Integration, edited by Robert Harmsen and Menno Spiering. European Studies 20. Amsterdam: Editions Rodopi.

Henderson, Karen. 2001. "Euroscepticism or Europhobia: Opposition Attitudes to the EU in the Slovak Republic.” SEI Working Paper No 50, Opposing Europe Research Network, Paper No. 5.

Hyman, Richard. 2001. "The Europeanization - or the Erosion - of Industrial Relation." Industrial Relations Journal 32(4): 280-94. 
Kabasakal, Hayat and Muzaffer Bodur. 2007. "Leadership and Culture in Turkey: A Multifaceted Phenomenon." Pp. 835-875 in Culture and Leadership Across the World: The Globe Book of In-Depth Studies of 25 Societies, edited by Chhokar Jagdeep, Felix Brodbeck and Robert House. London: Routledge.

Kentmen, Çigdem. 2008. "Determinants of Support for EU Membership in Turkey: Islamic Attachments, Utilitarian Considerations and National Identity." European Union Politics 9(4): 487-510.

Keyman, Fuat and Ahmet İçduygu. 2003. "Globalization, Civil Society and Citizenship in Turkey: Actors, Boundaries and Discourses.” Citizenship Studies 7: 219-234.

Koopmans, Ruud. 2007. "Who Inhabits the European Public Sphere? Winners and losers, supporters and opponents in Europeanized public debates." European Journal of Political Research 46(2): $183-210$

Krzyzanowski, M. and Oberhuber, F. 2007. (Un)doing Europe: Discourse and Practices in Negotiating the EU Constitution. Brussels: P.I.E.-Peter Lang.

Kvale, Steinar and Svend Brinkmann. 2009. Interviews, Learning the Craft of Qualitative Research Interviewing, $2^{\text {nd }}$ edition. California: Sage Publications.

Mair, Peter. 2007. "Political Parties and Party Systems." In Europeanisation: New Research Agendas, edited by Paolo Graziano and Maarten P. Vink. Houndmills: Palgrave Macmillan.

Marks, Gary and Marco Steenbergen. 2004. European Integration and Political Conflict. Cambridge: Cambridge University Press.

McLaren, Lauren and Meltem Müftüler-Bac. 2003. "Turkish Parliamentarians' Perspectives on Turkey's Relations with the European Union.” Pp. 195-218 in Turkey and European Union, Domestic Politics, Economic Integration and International Dynamics, edited by Ali Carkoglu and Barry Rubin. London: Frank Cass.

Milner, Susan. 2004. "For an Alternative Europe: Euroscepticism and the French Left Since the Maastrict Treaty." Pp. 59-81 in Euroscepticism: Party Politics, National Identity and European Integration, edited by Robert Harmsen and Menno Spiering, European Studies 20. Amsterdam: Rodopi.

Pasquier, Romain and Julien Weisbein. 2004. "L'Europe au microscope du local. Manifeste pour une sociologie politique de l'intégration communautaire." Politique européenne 12: 5-21.

Taggart, Paul and Aleks Szczerbiak. 2004. "Theorising Party-Based Euroscepticism: Problems of Definition, Measurement and Causality.” SEI Working Paper No. 69.

Yildırım, Engin. 2008. "Turkish Labour Confederations and Turkey's Membership of the European Union." Economic and Industrial Democracy, Vol. 29, No. 3, 362-387.

Van Disk, Teun A. 2000. “On the Analysis of Parliamentary Debates on Immigration.” Pp. 85-103 in The Semiotics of Racism, Approaches to Critical Discourse Analysis, edited by Martin Reisigl and Ruth Wodak. Vienna: Passagen Verlag.

Weiss, Gilbert and Ruth Wodak. 2003. "Theory and Interdisciplinarity in Critical Discourse Analysis. An Introduction." Pp. 1-34 in Theory and Interdisciplinarity in Critical Discourse Analysis, edited by Gilbert Weiss and Ruth Wodak. London: Palgrave Macmillan.

Wodak, Ruth. 2001. "The Discourse-historical Approach." Pp. 63-95 in Methods of Critical Discourse Analysis, edited by Ruth Wodak and Michael Mayer. London: SAGE.

Yalman, Galip. 2012. "Politics and Discourse under the AKP's Rule: The Marginalisation of Class-Based Politics, Erdoğanisation, and Post-Secularism." In Silent Violence: Neoliberalism, Islamist Politics and the AKP Years in Turkey, edited by Simten Cosar and Gamse Yücesan-Özdemir Ottawa: Red Quill Books.

Y1lmaz, Hakan. 2003. "Euroscepticism in Turkey: Doubts, Anxieties and Fears of the Turkish Public Concerning Europe and the European Union.” Open Society Institute. Istanbul. 